\title{
Mahseer, the history of the king of the river
}

\author{
Zainal A. Muchlisin ${ }^{1 *}$, Firman M. Nur ${ }^{2}$, Siti Maulida ${ }^{2}$, Luvi Syahfrida Handayani ${ }^{3}$ and Sri Riska Rahayu ${ }^{3}$ \\ ${ }^{1}$ Department of Aquaculture, Faculty of Marine and Fisheries, Universitas Syiah Kuala, Banda Aceh 23111, Indonesia \\ ${ }^{2}$ Graduate School of Mathematics and Applied Sciences, Universitas Syiah Kuala, Banda Aceh 23111, Indonesia \\ ${ }^{3}$ Integrated Coastal Management Postgraduate Program, Universitas Syiah Kuala, Banda Aceh 23111, Indonesia
}

\begin{abstract}
Mahseers (Cyprinidae) is one of the most important freshwater fish in Southeast Asia. This fish is being a consumption fish, ornamental and sport fishing. Mahseers can grow up to more than $30 \mathrm{~kg}$. Therefore, this species is called The King of The River. This paper reviewed some aspects of this interesting fish. A total of 54 papers have been reviewed where some of the papers come from our Ichthyos Research Group, Universitas Syiah Kuala. There are 50 species of mahseer throughout the world, where 20 species of which are found in Asia. Indonesia has four species of mahseer, namely; Tor tambra, T. tambroides, $T$. duorenensis, and T. soro, of which two species, T. tambra and T. tambroides are found in Aceh province. Between the two species, T. tambra has a wide distribution. The original habitat of the mahseer fish waters with speed currents, clear water, high dissolved oxygen, and low water temperatures. In the wild, mahseers migrate upstream for spawning during periods of high flooding in the early rainy season. The spawning occurs one or two months at the place that is inundated during floods. Mahseer is omnivorous, they fed on mollusks, aquatic plants, small fish, insects to fruits that grow on the banks of rivers. Mahseer fish in rearing ponds are often attacked by Lernea sp., Argulus sp., Trichodina sp., and Bothriocephalus acheilognathi worms
\end{abstract}

\section{Introduction}

Mahseers (Cyprinidae) is one of the most valuable river fish in Southeast Asia. Apart from being a consumption fish, this fish is also popular as an ornamental fish and for sport fishing [1-3]. This fish has a high nutritional value, good meat texture, and taste that makes this fish much sought after, hence making it one of the most expensive freshwater fish [3, 4]. Generally, these fish lives in waters that have relatively cold temperatures, clean and speed currents with rocky bottoms [4, 5].

In Aceh, this fish is a favorite for fishermen because it has a high selling price so that this fish becomes the main target for local fishermen [6]. Mahseers are one of the largest freshwater fish in Indonesia which can grow up to 30-45 kg. However, human activities such as dam construction and unfriendly fishing practices such as electric fishing, poison, and dynamite cause the population the fish have decreasing significantly [6]. Presently, the mahseers are rarely to catch, and the fish size is also smaller as an indication that overfishing. Therefore, currently, mahseer is listed in the IUCN Red List as an endangered species [7-9]; Therefore, it is necessary to conduct intensive research on various of bio-ecology, aquaculture development, and conservation plan [10].

Mahseer has the potential to be used as a cultured fish in Indonesia [11]; therefore catching mahseer from the wild has to be reduced or avoided, for that fishermen need to shift from fishing activity to cultivation [6]. Therefore, it is necessary to develop mahseer fish breeding technology both for cultivation (economic) purposes and for restocking (conservation), so that the supply of this fish can be met without disturbing its wild population. For example, the technique of domestication of mahseer broodstock has been developed by Muchlisin [11], and the breeding technique has been developed by Ingram et al. [12]. This article reviews several aspects of mahseer fish that have been studied and reported by several researchers including the results of our study.

\section{Morphology, diversity, distribution and conservation}

The mahseer has a total of four dorsal spines, and eight dorsal soft fin rays (D.IV.8), three anal spines, and five anal soft rays (A.III.5), and 39-41 vertebrae [13]. The upper lip is curved upwards and backward, and with the median lobe pointing upwards. The fins are yellow during younger and turn black in adults. Adult fish can grow to one meter a maximum [13]. The shape, size, and length of the median lobe are common morphology used to distinguish species within the Tor genus [14], besides, the color of the scales and mouth structure are also frequently used to differentiate the mahseers species [15].

Mahseer is a common name for Tor group of fishes, this group comprises 50 species worldwide, and 20 species are found in Southeast Asia. The fish had the symbolic name "The king of the river" and "Fish of 
God" [16]. There are several local name for mahseer in Indonesia, namely; tambra (Jawa), sapaan (Kalimantan), semah (Sumatera), jurung (Sumatera), kelah (Melayu), garing (West Sumatra), and keureling (Aceh). Mahseer or keureling is one of the popular fish for consumption, and sport fishing [17]. The fish can grow up to above 30 $\mathrm{kg}[14,18,19]$, and therefore the mahseer is one of the bigger fish in the river.

Indonesia has at least four species of mahseer, namely; Tor soro, T. tambra, T. douronensis and $T$. tambroides [20, 21], while in Aceh province has two valid species of mahseers, namely; T. tambra dan $\mathrm{T}$. tambroides (Figure 1). Presently morphological based observation especially on the presence or absence of lobes on the lower lip and the size of the lobes were used to distinguish between species of mahseers in Indonesia $[7,22]$; but this method is considered less accurate to distinguish to the species level and therefore other more accurate methods have been developed by using the COX1 marker gene or commonly known as DNA barcoding [23-27]. For example, based on morphological observation, there are three presumed species of Tor occurring in Aceh water, but after clarified by DNA barcoding there are only two valid species (T. tambra and T. tambroides) (Muchlisin et al., submitted paper).

In Aceh, the mahseers is distributing over the regions including Aceh Barat, Nagan Raya, Aceh Selatan, Aceh Tenggara, Aceh Besar, Pidie, and Gayo Lues [6, 28-32], and Aceh Jaya [33]. Mahseers conservation program have been carried out in several areas, for example in Jambi, West and North Sumatra Provinces by establishing a reservation area called "lubuk larangan", for instance; Lubuk Larangan Lobu Sangkunur in North Sumatra, Lubuk Larangan Sikucur in Padang Pariaman, West Sumatra, and Lubuk Larangan Beringin, Jambi. But unfortunately in Aceh, the conservation of this fish has not been initiated, while the population decline is more intense over the years.

Lubuk larangan is established and managed by indigenous peoples. The community is prohibited from catching fish in that locations for a certain period of time, and if there are violations of the rule, they will be subject to customary sanctions in the form of fines, such as having to pay a certain amount of food, a goat or even a buffalo depending on the scale of the violations. As one of the provinces that has the big potential for mahseer, Aceh should also develop rules, both community-based or those initiated by the government to establish river conservation areas in Aceh, so that not only mahseers would be protected but also other fish in the areas.

\section{Habitat, reproduction and breeding}

The original habitat of mahseer is in the upstream area of the river in mountain areas which is characterized by strong currents, clear water, high dissolved oxygen content, and relatively low water temperature $\left(<25^{\circ} \mathrm{C}\right)$ with rock bottom [16, 18, 34]. Mahseers fed on both plant and animal-based foods, and therefore they are omnivores $[35,36]$. In the wild, mahseers migrate upstream for spawning during periods of high flooding, and the spawning season is limited to one or two months [12]. This is an agreement with Desai [37] who stated that freshwater fish generally spawn during the rainy season. Mahseers are similar to other freshwater fish, they spawn in places that are inundated during floods $[38,39]$.

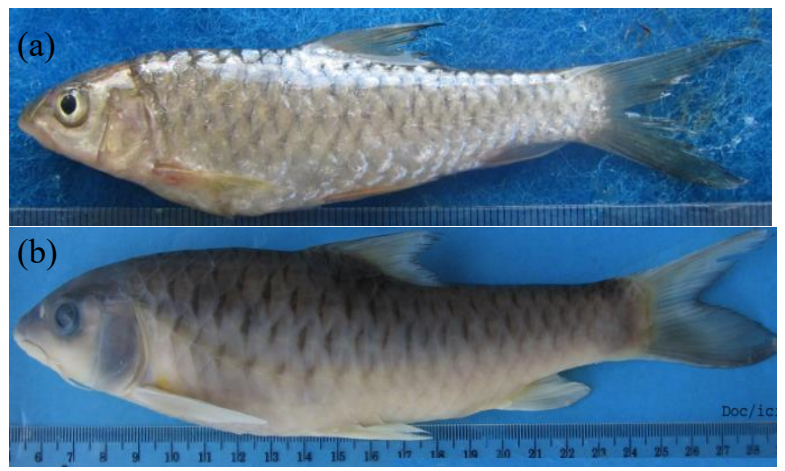

Fig. 1. Mahseer fish occurs in Aceh waters; (a) Tor tambra, (b) Tor tambroides.

Study on the reproduction of mahseers over the last two decades has developed an effective and productive spawning method [3]. Ingram et al. [12] is a pioneer in mahseer spawning research, who has conducted a threeyear trial of spawning using hormone treatments and resulted in significant findings and insights on mahseer breeding. The best hormonal treatment was Ovaprim with a dose of $0.5 \mathrm{ml} \mathrm{kg}^{-1}$, the success rate of spawning induction also increased dramatically with the administration of Ovaplant at a dose of 28-68 $8 \mathrm{~g} \mathrm{~kg}^{-1}$ with pre-treatment two to seven months before treatment [12]. In addition, immersing eggs in formalin solution is very important to prevent fungus infection and increases egg hatchability [12]. Ingram et al. [40] also reported that the best interval time for breeding was 30 days, but if it was shorter than 30 days, it was suspected that it would have an impact on sperm quality decreasing.

According to Gaffar et al. [41] and Sabar and Rachmatika [42], the fecundity of mahseers ranges from 9,180 to 100,000 eggs. Meanwhile, Rupawan and Husnah [43] stated that female mahseer had a fecundity of 11,689-14,433 eggs. However, fish fecundity, in general, is highly dependent on the size and age of the fish, where the bigger fish is produced more eggs than the smaller ones [44]. Mahseer eggs will hatch 48 hours after fertilization [42]. The age of the first sexually mature mahseer fish is over two years, the size of the male fish at the same age is smaller than the female [16].

\section{Feeding and nutrition requirements}

Mahseers are omnivores, they fed on molluscs, aquatic plants, algae, worms, small fish, and insects $[3,6]$. In addition, mahseers have a unique food preference for fruits with high protein energy content such as Shorea macrophylla and Ficus sp. [6, 45]. Mahseer fish harvested from the west coast of Aceh most preferred algae and worms as food [6]. Tan [39] also reported that 
in addition to liking brown and green filamentous algae, T. tambroides in certain seasons, they also fed ripe fruit and seeds of Ficus vareigata, Dipterocarpus oblongifolius, and Eugenia sp.

In some areas including Aceh, mahseer has been reared in ponds and floating cages in rivers. According to Halver [46], fish require protein as their main energy source. The research results of Muchlisin et al. [47] also showed that fingerling mahseer requires a minimum of $30 \%$ protein for optimal growth. The growth of mahseer $\mathrm{T}$. tambra in rearing ponds can be increased by the addition of vitamin $\mathrm{E}$ as much as $300 \mathrm{mg} \mathrm{kg}-1$ of feed [48] and papain enzyme as much as $27.5 \mathrm{mg} \mathrm{kg}-1$ [49] and the addition of probiotics in the feed as much as 10 $\mathrm{ml} \mathrm{kg}{ }^{-1}$ [47].

\section{Parasites}

Fish diseases are generally divided into two types, namely infectious and non-infectious diseases. Infectious diseases are caused by pathogens, such as bacteria, fungi, and viruses. While non-infectious diseases are caused by chemical and physical environmental factors for example; poisoning and malnutrition [50]. Lernea sp. is common exto-parasite attack mahseer in cultivated ponds [51]. Apart from Lernea, Argulus and Trichodina are also frequently attack mahseers in aquaculture ponds [51]. In addition to exto-parasites, mahseer fish in rearing ponds was also often attacked by endo-parasites especially the Asian fish tapeworm, Bothriocephalus acheilognathi [52]. To avoid parasitic infection on fish is to keep the pond environment clean and eradicate parasitic hosts, such as snails and wild fish. In addition, filtration of water entering the rearing pond, isolation of infected fish, and drying of the pond can also reduce the risk of cultured fish infecting parasites and disease [53, 54].

\section{Conclusion}

Mahseer is one of the bigger freshwater fish that lives in rivers. This fish has high economic value and its distribution is mostly in the Asian region. Indonesia has four species of mahseer, namely Tor soro, $T$. tambra, $T$. douronensis and T. tambroides. While in the waters of Aceh there are two valid species, namely T. tambra and T. tambroides. This fish spawns in the early of the rainy season and this fish is an omnivore. Mahseer fish in rearing aquaculture ponds were often attacked by ectoparasites Lernea, Argulus, and Trichodina, while endoparasites from the worm Bothriocephalus acheilognathi was also frequently found in the alimentary tract of mahseer. In rearing ponds, mahseer fingerling fish require feed with a minimum protein content of $30 \%$, and their growth can be increased by adding vitamin $\mathrm{E}$, papain enzymes, and probiotics to the feeds.

\section{References}

1. V. Mohindra, P. Khare, K. Lal, P. Punia, R. K. Singh, A. Barman,W. S. Lakra. Acta Zool Sin. (2007)

2. N. Shahi, S. K. Mallik,D. Sarma. Aquac Asia. 14, 22 (2014)

3. M. M. L. Lau, L. W. K. Lim, S. D. Ishak, A. B. Abol-Munafi,H. H. Chung. Proc Zool Soc. 74, 227 (2021)

4. L. K. Soon, S. Lihan, F. F. G. Dasthagir, K. M. Mikal, F. Collick,N. K. Hua. Int J Sci Technol Res. 3, 285 (2014)

5. T. K. Shrestha. The mahseer in the rivers of Nepal disrupted by dams and ranching strategies (1997)

6. Z. A. Muchlisin, A. S. Batubara, M. N. S. Azizah, M. Adlim, A. Hendri, N. Fadli, A. A. Muhammadar,S. Sugianto. Biodiversitas. 16, (2015)

7. M. Kottelat, A. Whitten, S. Katikasari,S. Wirjoatmodjo. Ikan air tawar Indonesia bagian Barat dan Sulawesi (1993)

8. U. Sarkar, B. Mahapatra, S. R. Saxena,A. Singh. J Ecophysiol Occup Health. 15, 45 (2015)

9. M. Kottelat, A. Pinder,A. Harrison. Tor tambra. The IUCN Red List of Threatened Species 2018: e.T188012A89801879 31 October 2021.(2018)

10. C. Kulkarni,S. Ogale. The present status of mahseer (fish) and artificial propagation of Tor khudree (Sykes) 651 (1978)

11. Z. A. Muchlisin. JII. 13, 91 (2013)

12. B. Ingram, S. Sungan, G. Gooley, S. Y. Sim, D. Tinggi,S. S. De Silva. Aquac Res. 36, 983 (2005)

13. Bleeker. Tor tambroides 1854)

14. Z. Wei,G.-H. Cui. Ichthyol Explor Freshw. 7, 131 (1996)

15. S. Siraj, Y. Esa, B. Keong,S. Daud. Malays Appl Biol. 36, 23 (2007)

16. N. C. Kiat. Kings of the rivers : Mahseer in Malaysia and the region (2004)

17. V. Desai. Synopsis of biological data on the tor mahseer Tor tor (Hamilton, 1822) (2003)

18. S. J. Haryono. Biodiversitas. 9, 306 (2008)

19. H. M. Smith. Bull US Natl Mus. 188, 9 pls. (1945)

20. S. S. De Silva, B. Ingram, S. Sungan, D. Tinggi, G. Gooley,S. Y. Sim. Aqua Asia. 9, 15 (2004)

21. H. Haryono. Biodiversitas. 7, (2006)

22. T. R. Roberts. Raffles Bull Zool. 47, 225 (1999)

23. R. Floyd, E. Abebe, A. Papert,M. Blaxter. Mol Ecol. 11, 839 (2002)

24. S. N. Farhana, Z. A. Muchlisin, T. Y. Duong, S. Tanyaros, L. M. Page, Y. Zhao, E. A. Adamson, M. Z. Khaironizam, M. de Bruyn,M. N. S. Azizah. Sci Rep. 8, 1 (2018)

25. P. D. N. Hebert, A. Cywinska, S. L. Ball,J. R. deWaard. Proc Biol Sci. 270, 313 (2003) 
26. Z. A. Muchlisin, Z. Thomy, N. Fadli, M. A. Sarong,M. N. Siti-Azizah. Acta Ichthyol Piscat. 43, (2013)

27. Z. A. Muchlisin, A. S. Batubara, N. Fadli, A. A. Muhammadar, A. I. Utami, N. Farhana,M. N. SitiAzizah. F1000Research. 6, (2017)

28. Z. Muchlisin,M. S. Azizah. Int J Zool. 5, 62 (2009)

29. Y. Akmal, Y. Dhamayanti,E. Paujiah. Biodiversitas. 21, (2020)

30. T. F. Haser, M. S. Nurdin, E. Supriyono, D. Radona, F. Azmi, K. Nirmala, T. H. P. Widanarni, T. Budiardi,R. Y. Valentine. (2021)

31. A. Hendri,S. Wahyuni. JPTropis. 3, (2016)

32. S. Zuraidah, B. Budiman,E. Safutra. J Akua. 2, (2018)

33. M. R. M. Radhi, I. Zulfahm,Y. Akmal. Prosiding Biotik. 8, (2021)

34. Haryono. (1994)

35. S. Sulastri, I. Rachmatika,D. Hartoto. Berita Biol. 3, 84 (1985)

36. Haryono. Perikanan dan aspek budidaya pada masyarakat Dayak di sekitar Cagar Alam Kayan Mentarang Kalimantan Timur; 1992; Kota Kinabalu.

37. V. Desai. Indian Nat Sci Acad. 39, 228 (1973)

38. K. Alikhuni,S. Rao. Jerdon Rec Indian Mus. 49, $157(1951)$

39. E. S. Tan. Aquaculture. 20, 281 (1980)

40. B. Ingram, S. Sungan, D. Tinggi, S. Y. Sim, S. S. De Silva. Aquac Res. 38, 809 (2007)
41. A. Gaffar, A. Utomo,S. Adjie. BPPD. 10, 17 (1991)

42. F. Sabar,I. Rachmatika. Zoo Indonesia. (1983)

43. A. Rupawan,G. Husnah. JPII. 5, 1 (1999)

44. Z. Muchlisin, M. Musman,M. S. Azizah. Reprod Biol Endocrinol. 8, 1 (2010)

45. M. S. Kamarudin, M. L. Bami, A. Arshad, C. R. Saad,M. Ebrahimi. Fish Sci. 84, 385 (2018)

46. J. Halver. Fish nutrition (2013)

47. Z. A. Muchlisin, T. Murda, C. Yulvizar, I. Dewiyanti, N. Fadli, F. Afrido, M. N. SitiAzizah,A. A. Muhammadar. F1000Research. 6, 1 (2017)

48. Z. A. Muchlisin, A. A. Arisa, A. A. Muhammadar, N. Fadli, I. I. Arisa,M. N. Siti-Azizah. Fish Aquatic Sci. 24, 47 (2016)

49. Z. A. Muchlisin, F. Afrido, T. Murda, N. Fadli, A. A. Muhammadar, Z. Jalil,C. Yulvizar. Biosaintifika. 8, 172 (2016)

50. Z. Muchlisin. Pengantar akuakultur (2019)

51. Z. A. Muchlisin, A. M. Munazir, Z. Fuady, W. Winaruddin, S. Sugianto, M. Adlim, N. Fadli,A. Hendri. Hum Vet Med. 6, 148 (2014)

52. Z. Muchlisin, Z. Fuadi, A. Munazir, N. Fadli, W. Winaruddin, C. N. Defira,A. Hendri. Bulg J Vet Med. 18, 361 (2015)

53. Z. Kabata. Parasites and diseases of fish cultured in the tropics (1985)

54. E. Soulsby. Helminths, Arthropods and Protozoa of domesticated animals (1982) 